Article

\title{
A Thoughtful Insight on Women Entrepreneur's Investment Attitude
}

\author{
Batool Muhammad Hussain ${ }^{1}$, Umair Baig ${ }^{2}$, Vida Davidaviciene ${ }^{3}$ and Ieva Meidute-Kavaliauskiene ${ }^{3, * \mathbb{D}}$ \\ 1 Management Sciences, Mohammad Ali Jinnah University, Karachi 75400, Pakistan; \\ batoolhuzaifah@gmail.com \\ 2 Commerce Department, Benazir Bhutto Shaheed University, Karachi 75660, Pakistan; umaiirbaig@gmail.com \\ 3 Department of Business Technologies and Entrepreneurship, Vilnius Gediminas Technical University, \\ 10223 Vilnius, Lithuania; vida.davidaviciene@viniustech.lt \\ * Correspondence: ieva.meidute-kavaliauskiene@vilniustech.lt
}

Citation: Hussain, Batool Muhammad, Umair Baig, Vida Davidaviciene, and Ieva

Meidute-Kavaliauskiene. 2021. A Thoughtful Insight on Women Entrepreneur's Investment Attitude. Economies 9: 187. https://doi.org/ 10.3390/economies 9040187

Academic Editor:

Aleksander Panasiuk

Received: 17 October 2021

Accepted: 17 November 2021

Published: 1 December 2021

Publisher's Note: MDPI stays neutral with regard to jurisdictional claims in published maps and institutional affiliations.

Copyright: (c) 2021 by the authors. Licensee MDPI, Basel, Switzerland. This article is an open access article distributed under the terms and conditions of the Creative Commons Attribution (CC BY) license (https:// creativecommons.org/licenses/by/ $4.0 /)$.
Abstract: This study endeavors to be cognizant of the investment paradigm of women entrepreneurs and reveal their ambitions, professionalism, and desire to form a robust framework in the context of economic development. These persistent attributes of women entrepreneurs for economic development persuaded us to investigate factors that influence women's attitude to make a long-term investment decision in their business regardless of uncertainty. This study adopted a deductive approach and assessed data using the PLS-SEM technique through Smart PLS 3.3.3. Around 330 adequate responses from Karachi and Lahore using a self-designed structured questionnaire revealed that women's investment attitude has a positive significant mediating effect on social, behavioral factors, and investment decisions. Whereas, women's investment attitude did not depict a positive significant mediating effect on personal factors and investment decisions. It was quite interesting to know that uncertainty did not reveal a significant moderating effect between investment attitude and investment decision. The study highlights measures suggested empowering women entrepreneurs who strive to enhance their performance and achieve sustainable development goals without being discouraged by society. Moreover, focusing risk-taking attributes to set an example for those who do not come forth. The novelty of the study in the context of women entrepreneur's investment attitude well contributes to the existing literature and recommends future scholars to expand the horizon of the existing area of the study in the context of cultural, demographic, and seasonal factors, which are also affecting women entrepreneur's investment decisions.

Keywords: social factors; personal factors; behavioral factors; uncertainty; and women investment decisions

\section{Introduction}

The word entrepreneur originates from the root words entre refers to "enter", pre refers to "before" and neur stands for "nerve-center". Briefly, one enters a business at a certain time to form meaningful change such as nerve or decision center (McKay 2001). Similarly, Cooke and Xiao (2021) highlighted that entrepreneurship refers to the level of motivation and capability that enables to commence, organize, and develop a business with a certain level of risk. Moreover, entrepreneurship does not only refer to beginning a new enterprise, rather it requires a core mindset with creative and strategic thinking and vision even in uncertain conditions. Thus, it cannot be denied that entrepreneurial activities contribute a major portion to grow economically in a country, through implementing several policies regarding entrepreneurs. Zeb and Ihsan (2020) argued that Pakistan being a developing state comprises an estimated population of 207 million includes approximately $49.2 \%$ women but women's participation in an economic expansion is less compared to men, which might be because of gender discrimination. Global Gender Report circulated in 2021 disclosed "The World Economic Forum" that among 156 nations, Pakistan is in 
153rd position based on gender parity and it demonstrates the lowermost rate of woman entrepreneurs globally owing to several social and cultural factors. The Pakistani government is striving to empower the youth and bolster the entrepreneurial ecosystem in our motherland. Similarly, according to the state-owned associated press of Pakistan program "PM's Start-up Pakistan" is also launched to boost entrepreneurs. Hence, women globally make a majority of purchasing decisions moreover, their economic empowerment is considered the biggest occurring change in our social lives (Lakshmi 2015).

Scholars have discussed comprehensively on behavioral finance and they have analyzed investors' behavior to make us aware of how investors manage to invest locally and internationally. Recent studies have witnessed individuals' personal qualities and traits influence their behavior, risk perception, and willingness to make different decisions. Thus, these personal attributes that influence investment attitude and performance still need to be explored on a wider scale (Akhtar et al. 2018). Eysenck (1991) studied that personal attributes comprise five principles facsimile, inclusiveness, external-correlates, source traits, and multiple levels. These principles were renamed as Five-Factor Model. On contrary, an investor is also affected by societal factors while performing investing activities such as media, social networks with friends and kinsfolks, electronic media i.e., the internet that has become an essential source to exchange information. Several studies also explain that behavioral finance discusses investors' decision that is affected due to emotional and psychological factors and several other factors that drive the investor's decisions (Davis 2006; Shiller 2000). Social interactions with friends and family greatly affect investment decisions as well as returns. Moreover, interaction with one another helps in seeking rational information to make final investment decisions (Shiller and Pound 1989).

Baporikar and Akino (2020) explored that collateral security, imperfect business services, asymmetry flow of information, and loans with high interest are a few issues that make financing and its accessibility difficult. This indicates a knowledge gap in entrepreneurs who are unaware of the potential information that banks need. Today knowledge is considered a critical resource, for any organization's growth, progress, and sustainability. Financial literacy or learning widens access to relevant information, provides better knowledge to make long-term decisions and survive successfully.

Hence, women entrepreneurs require proper training with adequate knowledge and relevant information that enable them to access finance easily from distinct financial institutions. Besides, Baum and Ingram (1998) suggested that gaining external knowledge makes competent, enhances the base of knowledge, improves technological proficiencies, and helps generate profit for the ventures. The reason behind equipping them with sound knowledge is to make better financial decisions that are highly affected and influenced by emotional outcomes. Investors' behavior changes or alters according to different markets and conditions therefore, it is necessary to inculcate psychological factors in finance too. Thus, keeping in view behavioral finance principles would mount a substantial amount of profits for the entrepreneurs as investors. The reason behind focusing on women in this study is to highlight issues that educate the future generation of the nation, which means to provide them with potential knowledge and such entrepreneurial expertise so that they can overcome the upcoming challenges. Moreover, to enable them to generate such ideas that can equip themselves with innovations and transfer the same to make a better place to live in (Baporikar and Akino 2020). Several developing and developed countries in the past as well as in the present are still facing financial crises, and their markets have been witnessing and observing volatility for years. This vulnerability has led to increased uncertainty. Previous studies have comprehensively discussed numerous factors regarding women entrepreneur startups considering the incubators who facilitate them to accelerate their business successfully in the market.

In contrast, Kappal and Rastogi (2020) explored the personal financial decisions of women entrepreneurs. Whereas, this study proposes those underlying factors that highly influence women's attitude towards financial investment decisions in the context of Pakistan. Women entrepreneurs in Pakistan tend to grow substantially, simultaneously; they 
are also highly affected by social, personal, and behavioral factors. Therefore, the research aims to discuss and highlight the issue that women entrepreneur suffers while making their capital investment decisions. These decisions to maximize their returns require sufficient financial knowledge, training, and societal encouragement and motivation so that they are capable enough to overcome uncertain events in the prevailing market and sustain to contribute to the well-being of the society, community, and nation as a whole. The research gap of the current study underlies the understanding of the crucial aspects of identifying decisions concerning women business owners while making capital investments, pertaining to running a successful business in two large and cosmopolitan cities Lahore and Karachi of Pakistan. Furthermore, analyzes the importance of influencing factors towards various long-term investments that still need attention because female business is a rising segment in the capital investor's population that needs attention in Pakistan.

Pakistan is a nation where women entrepreneurs can play an integral role in economic development. Women entrepreneurs through this study will be encouraged and motivated to accelerate the economic status for future sustainability. Moreover, the female population running their business to form capital will invest their surplus in different productive investment projects to lead to rapid growth in the country. Resources like wealth and national income in the form of goods and services help to increase entrepreneurial activities and contribute to society as a whole. Therefore, if women actively maintain, sustain, and diversify their investment strategies so this will ultimately contribute to the economy. Furthermore, creating a trade-off between risk and return would generate more commercial activities in the foreign market. This in return will also generate revenue for the country so that the economy can utilize the funds in the capital expenditure projects and somehow produce more potential business leaders within their skills and capacities.

Hence, after reviewing the past literature. These are the following core objectives of the study; 1 . to explore the investment attitude mediates with social factors and investment decisions. 2 . To explore the investment attitude mediates with personal factors and investment decisions. 3. To explore the investment attitude mediates with behavioral factors and investment decisions. Moreover, the fourth objective of the study is to explore the uncertainty moderates with investment attitude and investment decisions. Likewise, this study has included women entrepreneurs who are running their business in distinct sectors of the economy, for instance, education services, event management, app services, beauty salons, food catering, tailoring business, women-owned clinics, women IT business, etc. This facilitates policymakers and government officials to understand women's entrepreneurial empowerment for individual and family well-being in the light of cultural, economic, and institutional obstacles. The theoretical contribution derived from this study in the emerging world demonstrates women's pervasive contributions to their families, households, and overall economic development through well-being.

\section{Literature Review}

Investment Decisions highly influences others' personality, opposite or same gender, social and economic attitudes, faith, beliefs, and demographics. This helps us to understand their significant investment interest, psychology, and the influential decision-making factors. Several studies regarding behavioral finance have developed interest among various scholars and industries. Kahneman and Tversky (1988) criticized the theory of utility and they constructed an alternate model of prospect theory, which proved successful in the behavioral finance sphere. This success helped scholars to understand the deviation of human decisions at times of uncertainty because during unexpected and uncertain times an individual changes his/her decisions from the expected estimated outcomes employing Standard Economic Theory.

Investment Attitude comprehensively discusses the determinants of individual decisions, taken for investment purposes because investment behavior is mainly determined by the level of their financial knowledge or literacy and mathematical expertise. Several studies have pointed out numerous factors exceedingly affecting the financial decision of 
the investors because it is common in human nature that they don't make rational decisions every time (Nigam et al. 2018; Kumar et al. 2018). The decisions which an individual takes are biased to an extent that depends on their respective personality, sex, intuitions about earning money (Baker et al. 2018; Chavali and Raj 2016). Thus, it is a natural phenomenon that market sentiments and human personality affect long-term financial judgments. Thus, it is essential to explore what causes investors to behave in such a manner.

Behavioral Factors in Investment Decisions refers to investors being biased when they engage in investment (Fisher and Statman 2000; Kumar and Goyal 2015; Godoi et al. 2005). Similarly, Godoi et al. (2005) discussed imperfect cognitive reasoning, emotions, or sentiments that heavily affect personal investment decisions and enforce them to make irrational financial decisions because cognitive biases are derived from flawed reasoning, time constraint, heavy responsibilities, and lack of attention. Similarly, overconfidence bias germinates when the investor overestimates their abilities of judgment and pays less attention to negative information (Barber and Odean 1998; Fisher and Statman 2000). Mishra and Metilda (2015) stressed the self-attribution bias takes place when merchants receive credit for assisting investors to reap profit, and at times of losses, they blame external factors. Fisher and Statman (2000); Pompian (2006) have also pointed out additional cognitive biases such as ambiguity-aversion, representativeness, mental-accounting, the illusion of control, authentication, framing bias, and hindsight. Hence, Godoi et al. (2005) emphasized emotional and loss-aversion biases that differ from expected financial conduct that is attributed to emotions based on judgments. Kahneman and Lovallo (1993) discussed other emotional biases such as endowment bias. Whereas, Pompian (2006) discussed optimism bias. Barber and Odean (1998) pointed out regret aversion bias.

Personal Factor in Investment Decisions refers that there is inconsistency in making a suitable capital investment and the type of the investor's personality will detrimentally affect its wealth. Hence, it is essential to hire consultants who better grasp the personality and offer sound knowledge of the investment to their potential entrepreneurs (Akhtar et al. 2018; Brown and Taylor 2014; Bucciol and Zarri 2017; Mayfield et al. 2008; Filbeck et al. 2005; Parsaeemehr et al. 2013; Kannadhasan et al. 2016). Knowledge about investments plays a crucial role and has currently gained valuable consideration and attention (Hsu et al. 2020). It is also witnessed empirically that fiscal knowledge put forth a substantial effect on bearing risk (Bazley et al. 2020; Bianchi 2018; Liao et al. 2017). Moreover, the entrepreneur can efficiently allocate their surplus funds to sustain (Almenberg and Dreber 2015; Anderson et al. 2017; Calcagno and Monticone 2015; Hsu et al. 2020; Stolper 2018; Van Rooij et al. 2011).

Similarly, Kappal and Rastogi (2020) emphasized in their studies and confirmed that well-informed, educated, and more financially skilled people can cope up with their finances, which as a result helps to make better decisions for investment. Therefore, it becomes necessary for women entrepreneurs to be financially literate and well-equip themselves. Financial knowledge is a life skill that will raise growth in the economy and overall well-being. Scholars also assert that refined people in terms of education are more concerned about their sustainability and they carry out their capital expenses more cautiously as compared to those who are less literate or unqualified.

Social Factors in Investment Decisions observe that investment behavior is affected by a positive approach to the social environment (Grohmann et al. 2015). Hibbert et al. (2004) pointed out that financial prudence demonstrated by family and parents significantly influences the financial wit of a young adult. Kappal and Rastogi (2020) also highlighted that financial socialization developed by parents increased investment habits in their adulthood. Besides this guidance of family, social factors such as friends, relatives, and print or digital media drive the financial decision (Akhtar et al. 2018). Similarly, women after experiencing several years of investment differ in their attitudes and they exhibit different biases while taking investment decisions because it is observed that experienced entrepreneurs make sound capital investments and are more overconfident than those having less experience (Mishra and Metilda 2015). Moreover, many other psychographic attributes, for 
instance, attitude, standards, and different lifestyles also influence financial decisions. Tang and Baker (2016) pointed out that individuals possessing high self-esteem will expose healthier financial behavior. Thus, it is presumed that the natives of an economy are responsible to make an adequate investment for their respective countries (Imtiaz et al. 2019; Lassoued and Guirat 2020; Van Truong et al. 2020). Moreover, Salim and Khan (2020) revealed that people are more concerned about the anecdotes that affect the industry's investment activity rather than the amendments of government rules and regulations.

According to Salim and Khan (2020), women make countless efforts in any activity collectively performed by them in their respective regions. Thus, scholars rightly proclaim that investment decisions are highly influenced by several psychological, social, and emotional factors of an individual investor. Thus, the key purpose that an investor possesses is to embrace a thoughtful investment activity that offers a high return on low-risk investments. Sarkar and Sahu (2018) investigated that people are risk-averse and they take investment decisions very cautiously that reaps sufficient return in the long term. Consistent with the above arguments women are contributing a lot in the long-term for the prosperity of the society this will ultimately help in uplifting the country's development schemes.

Uncertainty while Investment is well defined in financial economics that an optimistic attitude of an entrepreneur is one in which he/she overestimates the possibility of worthy consequences and undervalues the possibility of undesirable consequences. Thus, this leads to a more risk-taking personal trait in financial decisions (Kahneman and Lovallo 1993; Heaton 2002). Owners of different businesses participate in capital expenditure and diversify their funds but they consistently make inappropriate valuations of probabilities. Sometimes individuals tend to overestimate the possibility of worthy outcomes in financial decisions (Heaton 2002; Camerer and Lovallo 1999; Lee et al. 1991). Thus, this study investigates women entrepreneurs' attitudes at the time of uncertain conditions. On contrary, Son and Rojas (2011) indicated that when owners fail to detect issues giving birth to faulty decisions so they do not own enough financial learning and experience. Whereas, some risk factors are relatively easier to identify, such as poor weather, delayed material delivery, scarcity of labor, inexpert labor, errors in design, change in orders, distinct site conditions whereas, factors such as organizational dynamics are difficult to detect. Thus, through the above discussion, the study examines that although women are risk-averse and possess a conservative attitude towards investment decisions, they often fail to plan the future adequately due to scarce financial knowledge, lack of training to maintain diversified funds.

The literature displays research on the underlying factors that influence women's investment decision direct and through investment attitude considering uncertainty to find out the strengthening relationship of the conceptual framework. However, (Arafat et al. 2020; Marín et al. 2019; Stefan et al. 2021; Muhammad et al. 2021) explored that women's businesses offer the chance to save by generating wealth and investment opportunities that contribute to their economic well-being. Furthermore, to attain business sustainability, women entrepreneurs save and invest to generate sufficient income for the future. The role of women's businesses goes beyond their well-being to affect their families and communities. It is assumed that income generated by women's businesses plays a crucial role in the family, economic, and societal well-being. Therefore, women must have sound knowledge to sustain themselves in the long run. Thus, The Path-Goal Theory and Prospect Theory enables an entrepreneur to become a successful leader and influence others by their actions to attain their path goals in the field of entrepreneurship whereas, Prospect Theory guides the entrepreneur especially women to frame such situations regarding profits and losses that ultimately assist her attitude towards risk. Since it is a common phenomenon that business and investing funds involve risk. The higher the risk will generate higher the profits although it requires sound financial knowledge that every entrepreneur possesses to sustain and grow substantially. Thus, motivating entrepreneurs to achieve a competitive advantage. Few studies have cogitated on how women entrepreneurs invest under these underlying factors such as social, personal, and behavioral factors together with invest- 
ment attitude as a mediating variable and moderation of uncertainty between investment attitude and women investment decisions. Therefore, this study has focused in detail to the best of the investigators' erudition. The study after reviewing the past literature proposes the following hypotheses:

Hypotheses 1 (H1). Investment Attitude mediates with Social Factors and Investment Decisions.

Hypotheses 2 (H2). Investment Attitude mediates with Personal Factors and Investment Decisions.

Hypotheses 3 (H3). Investment Attitude mediates with Behavioral Factors and Investment Decisions.

Hypotheses 4 (H4). Uncertainty moderates with Investment Attitude and Investment Decisions.

\section{Methodology}

This study has adopted a deductive approach to survey potential respondents. Magazines, newspapers, articles, and journals of Web of Science were considered and read to better comprehend the current practices of Pakistani women entrepreneurs. This study collected primary data to survey the potential respondents, structural equation modeling (SEM) tabulated and critically analyzed the upcoming outcomes. The core objective of this study is to ascertain influencing factors that affect the investment attitude and final decisions of women entrepreneurs. A close-ended structured questionnaire was designed and developed, based on the literature of women entrepreneurs. The questionnaire entails two main parts where Part A covers general demographic information and Part B includes the selected items of the conceptual framework which is presented in Figure 1 of the study. The Following proposed model is based on several sources shown in Table 1 to support the construct and its items. The constructs of the prevailing study are measured on a Likert scale of Seven points delineated as "1 (Strongly Disagree) 2 (Disagree) 3 (Somewhat Disagree) 4 (Neither agree nor disagree) 5 (Somewhat Agree) 6 (Agree) 7 (Strongly Agree)".

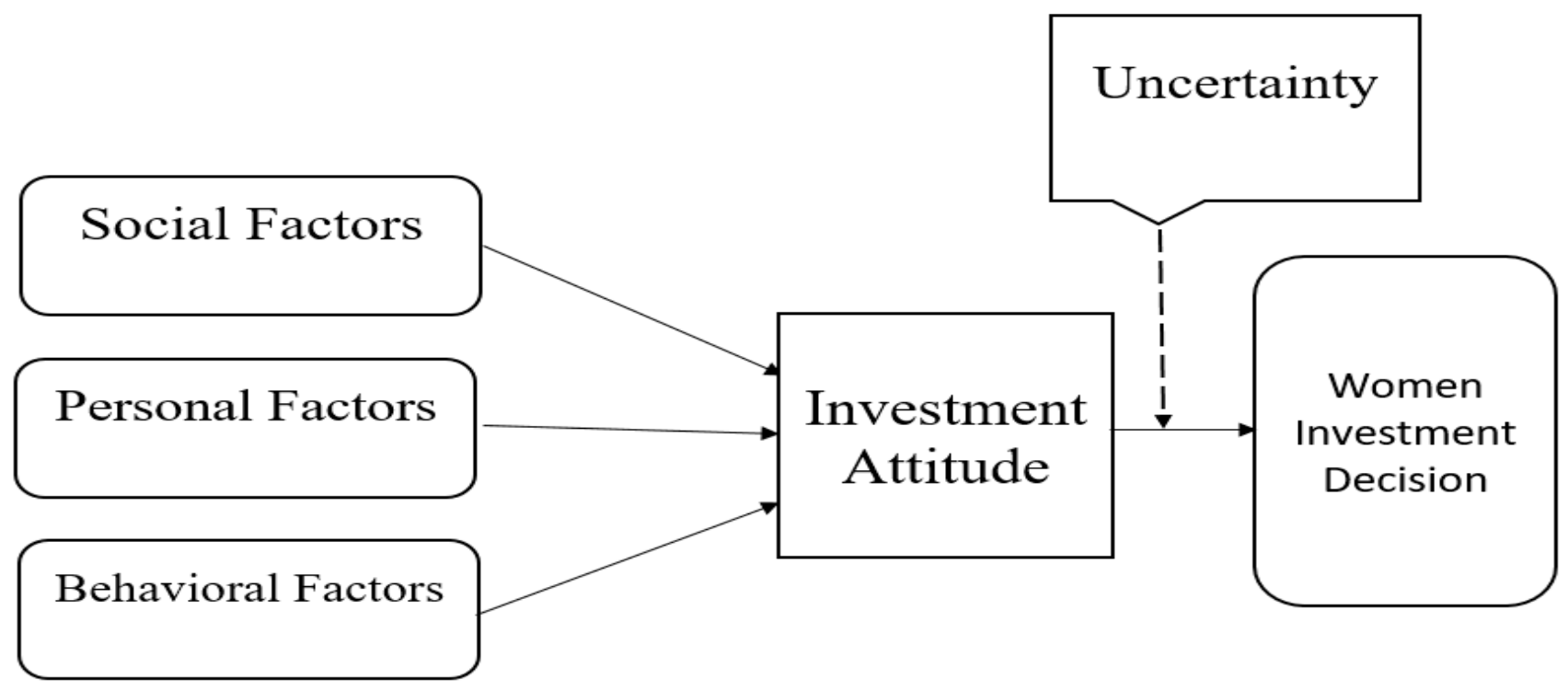

Figure 1. Conceptual Framework Associating Variables. 
Table 1. Sources to Support the Construct and its Items.

\begin{tabular}{|c|c|c|}
\hline Construct & Items & Supporting Literature \\
\hline Social Factors & 3 & $\begin{array}{c}\text { Nath et al. (2013); Bucciol and Veronesi (2014); Webley } \\
\text { and Nyhus (2006); Salim and Khan (2020); } \\
\text { Imtiaz et al. (2019); Akhtar et al. (2018); } \\
\text { Baker et al. (2018). }\end{array}$ \\
\hline Personal Factors & 3 & $\begin{array}{l}\text { Van Truong et al. (2020); Salim et al. (2016); Lee et al. } \\
\text { (1991); Baum and Ingram (1998); Sahi et al. (2013); } \\
\text { Soomro et al. (2020); Bucciol and Zarri (2017). }\end{array}$ \\
\hline Behavioral Factors & 3 & $\begin{array}{l}\text { Ritter (2003); Litt et al. (1992); Camerer and Lovallo } \\
\text { (1999); Thaler (2008); Son and Rojas (2011); Lakshmi } \\
\text { (2015); Heaton (2002); Trevelyan (2008); Wing Yan Man } \\
\text { (2006); Baporikar and Shikokola (2020); Benartzi and } \\
\text { Thaler (1995); Khresna Brahmana et al. (2012). }\end{array}$ \\
\hline Investment Attitude & 1 & $\begin{array}{c}\text { Sajjad et al. (2020); Kappal and Rastogi (2020); Zeb and } \\
\text { Ihsan (2020), Mayfield et al. (2008); Agarwal and Lenka } \\
\text { (2018); Chandra and Kumar (2012); Sarkar and Sahu } \\
\text { (2018); Zahera and Bansal (2018). }\end{array}$ \\
\hline Uncertainty & 4 & $\begin{array}{l}\text { Baum and Ingram (1998); Rashid and Ratten (2020); } \\
\text { Sarkar and Sahu (2018); Lakshmi (2015). }\end{array}$ \\
\hline Investment Decisions & 3 & $\begin{array}{l}\text { Benartzi and Thaler (1995); Shakeel et al. (2020); Mishra } \\
\text { and Metilda (2015); McColl-Kennedy and Anderson } \\
\text { (2005); Shiller (2000); Lassoued and Guirat (2020); } \\
\text { Bracha and Brown (2012); Pandian and Thangadurai } \\
\text { (2013); Shiller and Pound (1989). }\end{array}$ \\
\hline
\end{tabular}

This study has incorporated women entrepreneurs executing their business in different sectors of the economy, for instance, small businesses like education services, event management, app services, beauty salons, food catering, tailoring business, women-owned clinics, women IT business. Therefore, the relevant data is accumulated from the two big cities Lahore and Karachi that lie in the region of Punjab and Sindh from the period Jan 2020-Jan 2021. The study has used a Snowball sampling technique to gather the data. This is a non-probability technique which is also called "chain-referral sampling". It is used when the samples consist of certain traits that are rare to find. It helped us by providing referrals to enlist samples needed for our research.

A total of 800 questionnaires were circulated online, by email, and Google Form to our potential respondents out of which we just received 200 responses from Karachi and 225 from Lahore. These responses were further shortlisted. The shortlisting of the survey questionnaire helped to separate the most relevant responses as we found some responses were unengaged and most of them had missing values. Thus, in all 330 responses were incorporated and filled adequately i.e., 178 from Karachi which is 54 percent of the total selected sample, and 152 from Lahore which is 46 percent of the total sample selected in the study. Table 2 illustrates the demographic distribution of the ultimate respondents. 
Table 2. Demographic Distribution.

\begin{tabular}{|c|c|c|}
\hline Profile & Karachi \% & Lahore $\%$ \\
\hline \multicolumn{3}{|l|}{ Age (in Years) } \\
\hline 25 to 30 & $15 \%$ & $20 \%$ \\
\hline 31 to 35 & $25 \%$ & $19 \%$ \\
\hline 36 to 40 & $26 \%$ & $45 \%$ \\
\hline Above 40 & $34 \%$ & $16 \%$ \\
\hline \multicolumn{3}{|l|}{ Marital Status } \\
\hline Unmarried & $10 \%$ & $7 \%$ \\
\hline Married & $30 \%$ & $35 \%$ \\
\hline Divorced & $5 \%$ & $16 \%$ \\
\hline Widow & $55 \%$ & $42 \%$ \\
\hline \multicolumn{3}{|l|}{ Qualification } \\
\hline Non-Graduate & $12 \%$ & $13 \%$ \\
\hline Graduate & $14 \%$ & $26 \%$ \\
\hline Post Graduate & $67 \%$ & $56 \%$ \\
\hline $\mathrm{PhD}$ & $7 \%$ & $5 \%$ \\
\hline \multicolumn{3}{|l|}{ Experience (in Years) } \\
\hline 1 to 5 & $8 \%$ & $11 \%$ \\
\hline 6 to 10 & $26 \%$ & $36 \%$ \\
\hline 11 to 15 & $33 \%$ & $23 \%$ \\
\hline 16 to 20 & $28 \%$ & $20 \%$ \\
\hline Above 20 & $5 \%$ & $10 \%$ \\
\hline \multicolumn{3}{|l|}{ Income After Tax (000) } \\
\hline Rs. 100 and above & $4 \%$ & $3 \%$ \\
\hline Rs. 300 and above & $8 \%$ & $6 \%$ \\
\hline Rs. 500 and above & $30 \%$ & $25 \%$ \\
\hline Rs. 700 and above & $27 \%$ & $21 \%$ \\
\hline Rs. 900 and above & $31 \%$ & $45 \%$ \\
\hline \multirow[t]{2}{*}{ Where $\mathbf{n}=330$} & $\mathrm{n}=178$ & $\mathrm{n}=152$ \\
\hline & $54 \%$ & $46 \%$ \\
\hline
\end{tabular}

\section{Results}

\subsection{Assessment of Measurement Model}

The model of the study is reflective in nature that examines the indicator loadings. The recommended factor loadings must be above 0.708 . The constructs illustrating more than $50 \%$ of the variance among indicators, therefore, provide acceptable reliability of the item. After examining loadings then the next step is to assess internal consistency reliability through composite reliability (Jöreskog 1971). Higher values demonstrate greater reliability. For instance, values between 0.6 and 0.7 are accepted in exploratory research. Whereas, values in the range 0.7 and 0.9 are deemed good. Thus, to demonstrate validity and reliability of Social factors, Personal factors, and Behavioral factors, Investment Attitude, Uncertainty and Women Investment Attitude. Table 3 depicts the reliability and validity of the proposed constructs ranging from 0.713 to 0.884 i.e., above the threshold values therefore, there is more than $50 \%$ of the variance among indicators, which ultimately accepts the reliability of the items. 
Table 3. Construct Reliability and Validity.

\begin{tabular}{|c|c|c|c|c|}
\hline Constructs & CR & AVE & Items & Factor Loadings \\
\hline \multirow{3}{*}{ Behavioral Factors } & \multirow{3}{*}{0.832} & \multirow{3}{*}{0.625} & BF 1 & 0.884 \\
\hline & & & BF 2 & 0.751 \\
\hline & & & BF 3 & 0.727 \\
\hline Investment Attitude & 1.000 & 1.000 & IA 1 & 1.000 \\
\hline \multirow{3}{*}{ Personal Factors } & \multirow{3}{*}{0.765} & \multirow{3}{*}{0.523} & PF 1 & 0.631 \\
\hline & & & PF 2 & 0.713 \\
\hline & & & PF 3 & 0.814 \\
\hline \multirow{3}{*}{ Social Factors } & \multirow{3}{*}{0.810} & \multirow{3}{*}{0.587} & SF 1 & 0.802 \\
\hline & & & SF 2 & 0.734 \\
\hline & & & SF 3 & 0.761 \\
\hline \multirow{4}{*}{ Uncertainty } & \multirow{4}{*}{0.854} & \multirow{4}{*}{0.596} & UN 1 & 0.736 \\
\hline & & & UN 2 & 0.783 \\
\hline & & & UN 3 & 0.846 \\
\hline & & & UN 4 & 0.716 \\
\hline \multirow{3}{*}{ Women Investment Decisions } & \multirow{3}{*}{0.834} & \multirow{3}{*}{0.628} & WID 1 & 0.759 \\
\hline & & & WID 2 & 0.863 \\
\hline & & & WID 3 & 0.749 \\
\hline
\end{tabular}

The validity of the construct depicts the suite of measured items that exhibits the theoretic latent variable. Construct validity can be determined by observing the discriminant and convergent validity of each construct (Hair et al. 2014). To examine convergent validity, indicator loadings should be higher than 0.7 such as CR $>0.7$ and AVE $>0.5$ (Hair et al. 2019). Table 3 demonstrates the results of the factor loading, AVE, and CR. Factor loading of all items are above the threshold values as discussed above. Values of CR range from 0.765 to 0.854 . Similarly, AVE $>0.50$ depicts $50 \%$ and above variance of the construct's items. Thus, putting together the outcomes authenticates the convergent validity of the proposed model as shown in Figure 2:

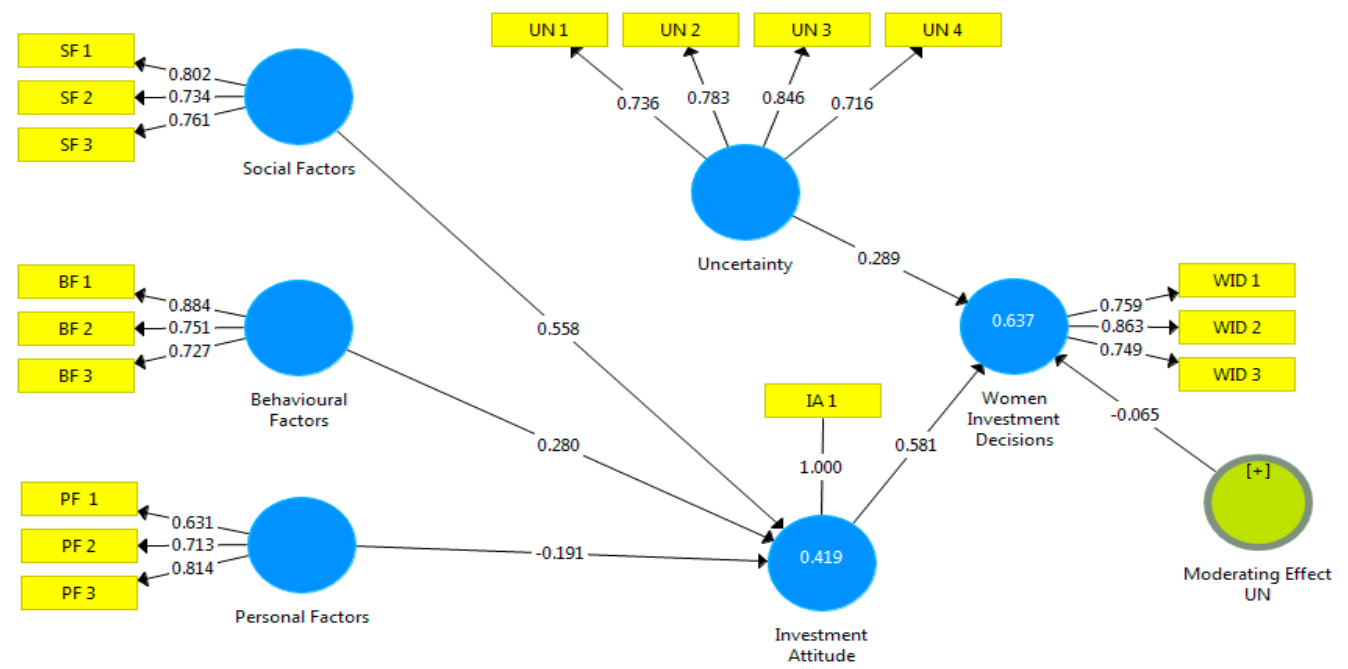

Figure 2. PLS-SEM Measurement Assessment Model.

Discriminant validity depicts that a variable or a construct is empirically different from other constructs in the given structural model. Fornell and Larcker (1981) proposed that the 
AVE of each construct is contrasted to the "Squared inter-construct correlation" of the same variable or construct. The AVE values must be greater than the inter-construct squared correlations. Table 4 illustrates that the diagonal bold values of AVE in each construct are greater than their squared correlations. This implies that each latent variable has appropriate discriminant validity which was ascertained by disseminating questionnaires to the potential women entrepreneur experts.

Table 4. Fornell-Larcker-Discriminant Validity.

\begin{tabular}{ccccccc}
\hline & BF & IA & PF & SF & UN & WID \\
\hline Behavioral Factors & $\mathbf{0 . 7 9 0}$ & & & & \\
\hline Investment Attitude & 0.577 & $\mathbf{1 . 0 0 0}$ & & & & \\
\hline Personal Factors & 0.754 & 0.475 & $\mathbf{0 . 7 2 3}$ & & & \\
\hline Social Factors & 0.791 & 0.814 & 0.624 & $\mathbf{0 . 7 6 6}$ & & $\mathbf{0 . 7 7 2}$ \\
\hline Uncertainty & 0.803 & 0.823 & 0.991 & 0.491 & 0.592 & $\mathbf{0 . 7 9 2}$ \\
\hline Women Investment Decisions & 0.732 & 0.752 & 0.516 & 0.67 & & \\
\hline
\end{tabular}

Note: Bold Diagonal values are the square roots of AVE.

\subsection{Assessing Structural Model}

After assessing the measurement model successfully, the results were subsequently evaluated through PLS-SEM structural model. The first step to assess the structural relationship is to examine collinearity to ensure there is no bias in the regression results through VIF (Variance Inflation Factor) shown in Table 5. The second step is to examine $\mathrm{R}^{2}$ (coefficient of determination) value of the endogenous construct. The values of VIF that are above 5 indicate collinearity issues among the predictor constructs. VIF values $\leq$ 3 are recommended to reduce the issue of biases in the regression results. Thus, Table 5 illustrates the VIF values that are less than equal to 3 ranging between 1.000 and 3.706 that eventually implying that there is no collinearity issue in the model.

Table 5. Collinearity Statistics (VIF).

\begin{tabular}{cl}
\hline Indicators & VIF \\
\hline SF 1 & 1.959 \\
\hline SF 2 & 1.642 \\
\hline SF 3 & 1.780 \\
\hline PF 1 & 1.502 \\
\hline PF 2 & 1.543 \\
\hline PF 3 & 1.609 \\
\hline BF 1 & 1.945 \\
\hline BF 2 & 2.000 \\
\hline BF 3 & 1.811 \\
\hline IA 1 & 1.000 \\
\hline Attitude * Uncertainty & 1.000 \\
\hline UN 1 & 3.122 \\
\hline UN 2 & 1.474 \\
\hline UN 3 & 1.751 \\
\hline
\end{tabular}


Table 5. Cont.

\begin{tabular}{cc}
\hline Indicators & VIF \\
\hline UN 4 & 3.706 \\
\hline WID 1 & 1.802 \\
\hline WID 2 & 2.564 \\
\hline WID 3 & 1.933 \\
\hline
\end{tabular}

Coefficient of Determination $\left(\mathrm{R}^{2}\right)$ measures the variance in endogenous construct titled Women Investment Decision. It is, therefore, an explanatory power (Shmueli and Koppius 2011). R-square is also known as the "In-sample predictive power" of values therefore, the larger the quantity of predicting constructs, the greater the value of $R^{2}$ (Rigdon 2012). Range of $R^{2}$ lies between 0 and 1 . For instance, the $R^{2}$ values that are $\geq 0.75$ are considered substantial, values of $\geq 0.50$ are considered moderate, whereas, values $\geq 0.25$ are frail (Hair et al. 2011; Henseler et al. 2009). Table 6 depicts $R^{2}$ values $=0.637$, which shows moderate explanatory power of the dependent variable.

Table 6. Coefficient of Determination $\left(\mathrm{R}^{2}\right)$.

\begin{tabular}{cc}
\hline Construct & R-Square \\
\hline Women Investment Decisions & 0.637 \\
\hline
\end{tabular}

\subsection{Significance of Hypothesis}

The occurrence of moderated mediation represents the strength of the indirect effect of one variable on the level of another variable. Briefly, when the mediation relationships are contingent on the level of a moderator. T-values in path analysis attempts to calculate the difference in paths between the groups of a given sample. Chin (2010) suggested a quick fix to deal with the estimates of the bootstrap re-sampling parametrically through T-test. Therefore, this study claims that equal variance of T-test can be applied since the prerequisite estimations are met.

Similarly, when the structural model associates independent, dependent, mediating, and moderating variables of this study so their paths form hypotheses accordingly. Thus, on the basis of these paths, this study accepts or rejects each designed hypothesis. These analyses provide knowledge and enable the formation of an opinion on the relationship among independent variables, dependent variables with mediated-moderating effects. Bootstrapping in PLS SEM allows generating the t-values and $p$-values to know the significance level. If $t$-value $\geq 1.96$ and $p$-value $\leq 0.05$ so the outcomes have met the level of significance. Path Analysis also helps to accept and reject the proposed hypotheses. Hence, Table 7 reveals specific indirect effects through path analysis where $\mathrm{H} 1$ and $\mathrm{H} 3$ are accepted and support the hypotheses $(\mathrm{t}=3.597, p=0.000 ; \mathrm{t}=2.173, p=0.03)$. On contrary, H2 and $\mathrm{H} 4$ are rejected and do not support the hypotheses $(\mathrm{t}=1.377, p=0.169 ; \mathrm{t}=1.733, p=0.084)$.

Table 7. Specific Indirect Effects.

\begin{tabular}{ccccc}
\hline Hypothesis & STDEV & T-Values & $p$-Values & Decisions \\
\hline H1: SF -> IA -> WID & 0.09 & 3.597 & 0.000 & Supported \\
\hline H2: PF -> IA -> WID & 0.08 & 1.377 & 0.169 & Not Supported \\
\hline H3: BF -> IA -> WID & 0.075 & 2.173 & 0.030 & Supported \\
\hline H4: IA -> IA * UN -> WID & 0.037 & 1.733 & 0.084 & Not Supported \\
\hline
\end{tabular}

\subsection{Path Coefficient Analysis}

The path coefficient between dependent, independent, and mediated-moderating variables are evaluated to test the hypotheses of the proposed study. Moreover, its values 
must between -1 and +1 to measure the specific effect within the model (Hair et al. 2011; Wetzels et al. 2009). The inner model in the figures below observes that hypothesized path association between Social, Behavioral, and Personal factors via Investment Attitude has the strongest effect on Women Investment Decision $(\beta=0.581)$ indicating statistically significant and hypothesized path association between uncertainty, Investment Attitude and Women Investment Decision $(\beta=-0.191)$ is not statistically significant. Thus, both the path coefficients are above standardized value $(\beta= \pm 1)$. It can be concluded Investment Attitude is a moderately strong predictor of Women's Investment decisions whereas, Uncertainty weakly predicts Women's Investment decisions. The assessed values of path coefficients shown in Figures 3 and 4 ensure empirical testing of the hypotheses at a significance level of 0.05 .



Figure 3. Path-Coefficient and T-Values.



Figure 4. Path-Coefficient and P-Values.

\section{Discussions}

The above results significantly support $\mathrm{H} 1$, which implies that investment attitude, mediates with social factors and investment decisions while making long-term capital decisions. They feel more secure with those decisions, which are preferred by their parents and social network around while performing investing activities. It is contended by different scholars that family, society, or community affects the financial literacy of adults. 
Thus, the findings of the study reveal that women entrepreneurs select among alternatives by keeping in view the investment choices of their surroundings (Grohmann et al. 2015). It is observed that young ones impersonate the investment behavior from their parents and the experiences of the community they belong (Webley and Nyhus 2006) which ultimately is reinforced when they reach their maturity level. Thus, in Pakistan social norms built up their attitude and then help them to make final investment decisions in different investment projects. Similarly, Women business owners are also persuaded by the negative experiences of people around them therefore, they engage an investment advisor or consultant who assists them to best utilize their funds for the investment purpose. Thus, this helps them to diversify their long-term investment. On contrary, those who do not consult financial advisors only make traditional investments.

Correspondingly, the results of the study do not support the second hypothesis H2 as mentioned in a section of literature that inconsistency in selecting capital investment and the type of the investor's personality will detrimentally affect its wealth. Therefore, it is essential to hire consultants who better grasp the personality and offer sound investment proposals to their potential investors (Akhtar et al. 2018; Brown and Taylor 2014; Bucciol and Zarri 2017; Mayfield et al. 2008; Filbeck et al. 2005; Parsaeemehr et al. 2013; Kannadhasan et al. 2016). Since it was observed that women hold a risk-averse attitude towards investments, therefore; it becomes difficult for them to delve into risky investments because most of the owners hold a bundle of responsibility to run their families. Personality traits however vary even if they are optimistic their attitude relies on the type of circumstances. It does not matter what personal attitude she possesses the only thing matters is to earn and become independent for their survival. As far as investment decisions are concerned, they lack financial knowledge and time to spend on understanding various investment projects. Very few of them allocate their funds for capital expenditure for instance opening a new outlet or franchise but this again requires sound knowledge and consultancy. Thus, the concept of personality relies on a particular consistency of performance of an individual relating to its present and past behavior. Disparate behaviors demonstrate correspondence over time. As it is witnessed, being an entrepreneur the motivational structure of a person is rigid and constant to an extent that does not affect their leadership style otherwise they can't carry on their business as entrepreneurs.

In contrast, the results supported the third hypothesis $\mathrm{H} 3$ as it was observed that women entrepreneurs are long-term investors therefore, they consider behavioral biases such as risk aversion and mental accounting. Although, they keep an optimistic approach and take risks in their business, but they avoid risks while making investment decisions. They prefer to invest in comfortable and secured projects. In Pakistan, they perceive themselves as long-term investors moreover, they utilize their surplus when they budget their expenditures. When they incur losses so they like better to wait until the next profitable investment. They do not believe to liquidate an investment in losses. It is observed that they daily re-assess their budgets. The current study witnessed three strong behavior all biases in women entrepreneurs of Karachi and Lahore city of Pakistan that greatly influence their financial investment decisions such as risk aversion, mental accounting, and optimistic approach. The respondents agreed that this will not adequately benefit them at the time of their retirement because their ultimate objective is capital appreciation (Baig et al. 2021). Hence, it can be concluded that they are not satisfied financially by their management and planning of investment due to imperfect financial literacy. Moreover, scarce time restricts them to study and understanding various investment projects. Thus, the behavioral factors inducing the investment attitude are affected by the investment acquaintanceship and time availability for investments that eventually cause financial gratification and long-term sustainability.

Finally, the outcomes of the study do not support the fourth hypothesis $\mathrm{H} 4$ as the study witnessed that uncertainty varies in different situations. For instance, according to Hsu et al. (2017), entrepreneurs' readiness to learn from failure changes as a function of the rate of failure so they mostly support approach-oriented appraisals by framing uncertainty 
or unexpected conditions as a learning opportunity. As it is observed that women are optimistic and also execute their business with more responsibility therefore, uncertain conditions also do not moderately affect their attitude and final investment decisions. They are well aware of unexpected events before their start-ups therefore, they are inclined to invest in secured investment projects and opportunities to sustain. Most of them are responsible to look after their families therefore, they hesitate to expand. Expansion in business and exploiting resources again require sound knowledge which is, unfortunately, less among women entrepreneurs. Our country, norms, culture, and traditions make them reluctant at small-scale businesses. Griffin and Grote (2020) also determined that uncertainty requires acquiring new and innovative information and knowledge about the changing world. This means that an entrepreneur sustains if it accepts challenges and innovations in the present to achieve reward in the future.

Thus, this study predicted that uncertainty would change the investment behavior therefore, to know the strength of the relationship among the variables the study attempted to empirically test the moderating effect. Eventually, the outcomes of the study did not depict a significant moderating effect of uncertainty between investment attitude and women's investment decisions. In Pakistan where individuals, especially women, are habitual of several political instabilities, economic instability, and market volatility therefore, uncertain circumstances do not affect small businesses like beauty salons, food catering, tailoring business, schools, women-owned clinics, women IT business. These sectors after a survey revealed that they in case of instability especially at a time of COVID 19 were not affected by the uncertain conditions rather their businesses were running well as before.

\section{Conclusions}

This study empirically intends to explore and examine women entrepreneurs' investment attitudes in two cosmopolitan cities Karachi and Lahore also considered startup initiators. This study encompasses four key objectives. The first three objectives discuss the mediation effect of investment attitude on social, personal, behavioral factors and women investment decisions. The fourth objective is to determine the moderating effect of uncertainty on investment attitude and women's investment decisions. The study exhibits the investment mindset of women business owners in urban Pakistan. Presently, women entrepreneurs are growing substantially, about $10 \%$ of total entrepreneur activity raised in the last two decades (Elam et al. 2019; Yaqoob 2020). Moreover, women as entrepreneurs are investors of long-run who possess a conservative attitude and frequently require financial consultants for any financial activity. Their investment preferences rely on the investment attitude of different social, personal, and behavioral factors but they strongly believe in becoming financially independent to take their own financial decisions. The problem that prevents them to expose themselves to risky investment is a lack of sound financial knowledge or limited knowledge regarding different financial projects or capital investments. If they acquire adequate financial knowledge about different investments and get enough time to understand the nature of investments so their exposure towards investment would extend and will diversify their funds as well.

\section{Implications}

The investment supervisor or manager will procure a sound insight regarding the psychology of female entrepreneurs in the field of investment. Moreover, will also enable them to progress personalized and pertinent proposals. As a result, this will also aid service facilitators to establish training institutions and different modules for women's investment consultants to meet the needs and wants of women entrepreneurs. The policymakers and research scholars can benefit from this study as it provides a deep understanding of the factors that indirectly affect the process of women entrepreneurs' decisions, through their investment attitude. Finally, women entrepreneurs would gain comprehensive knowledge about mitigating their prejudices, whilst corporate investments. Similarly, they will be able 
to draw wiser inferences, thereby lowering the risk and capitalizing on opportunities to sustain and expand their business globally.

This study will offer several opportunities to enhance gender equality among the pool of investors in society. Thus, it can be achieved if women in Pakistan are encouraged and are able to easily access proper training and education from field experts such as investment counselors or consultants. The study highly recommends well-organized workshops on investment awareness based on the outcomes of this research. Women entrepreneurs are triggering factors to start up and execute a prosperous business activity. Like men, women also possess the quality of self-actualization, hardworking, commitment, and continuous learning. They know how to exploit and employ resources productively and effectively. Thus, this study will also foster and raise different modes of qualifications by facilitating a promotion in the status of women in social activities.

\section{Limitation}

This study only exhibits social, personal, and behavioral factors that affect women's investment decisions indirectly through their investment attitude. Moreover, uncertainty is taken as moderating variable to know the influence of investment attitude on investment decisions. Other factors can be used that might affect their investment decisions. A total of 330 women were interrogated from Karachi and Lahore. A study similar to it can be conducted provincial-wise with a sample greater than it, to extend the knowledge provided by the existing research. Women entrepreneurs in different provinces and various other sectors of Pakistan will probably depict different investment attitudes of women while taking any investment decisions for their business.

\section{Contribution to the Society}

Emerging nations, like Pakistan, where a small number of women-owned businesses exist, face several challenges. Thus, to sustain a profitable business to further extend their business through various investment opportunities women entrepreneurs need to differentiate themselves from others through adaptability and sound knowledge. The current study reveals underlying factors that come across women's entrepreneurship and heavily influence their attitude towards final investment decisions. Therefore, women entrepreneurs must make every effort to improve their performance by updating themselves through various means without being discouraged by society and focusing on traits like risk-taking and achievements to set an example for those who do not come forth.

\section{Future Scope}

Since, Karachi and Lahore are two big cosmopolitan cities comprising different traditions, norms, and cultures. Therefore, authors can also research the influence of cultural factors affecting women entrepreneurs' attitudes in relation to corporate investments. Furthermore, scholars need to explore the association between entrepreneurship, modernization, and performance on Pakistani registered and unregistered women entrepreneurs. Recently, Zeb and Ihsan (2020) investigated the impact of small and medium-sized women entrepreneurs and innovation on the entrepreneurial performance in Pakistan with the mediating effect of innovation between women-owned business and performance in Pakistan. Although the results of the study exhibited that past experiences, society, families, and certain behavioral biases play a crucial role towards women entrepreneurs, still, the wide scope is assumed for a study that surveys the strength of other variables by conducting different investing behaviors of women investors, for instance, based on demographic and seasonal factors in the context of Pakistan.

Author Contributions: Conceptualization, U.B. and V.D.; formal analysis, U.B. and B.M.H.; investigation and methodology, U.B. and I.M.-K.; resources, B.M.H.; supervision, U.B. and I.M.-K.; validation, V.D.; writing-original draft, U.B. and B.M.H.; writing-review and editing, I.M.-K. and V.D. All authors have read and agreed to the published version of the manuscript. 
Funding: This research received no external funding.

Institutional Review Board Statement: Not applicable.

Informed Consent Statement: Not applicable.

Data Availability Statement: The data of this study is available from the authors upon request.

Conflicts of Interest: The authors declare no conflict of interest.

\section{References}

Agarwal, Sucheta, and Usha Lenka. 2018. Why research is needed in women entrepreneurship in India: A viewpoint. International Journal of Social Economics 45: 1042-57. [CrossRef]

Akhtar, Fatima, K. S. Thyagaraj, and Niladri Das. 2018. The impact of social influence on the relationship between personality traits and perceived investment performance of individual investors: Evidence from Indian stock market. International Journal of Managerial Finance 14: 130-48. [CrossRef]

Almenberg, Johan, and Anna Dreber. 2015. Gender, stock market participation and financial literacy. Economics Letters 137: 140-42. [CrossRef]

Anderson, Anders, Forest Baker, and David T. Robinson. 2017. Precautionary savings, retirement planning and misperceptions of financial literacy. Journal of Financial Economics 126: 383-98. [CrossRef]

Arafat, Mohd Yasir, Javed Ali, Amit Kumar Dwivedi, and Imran Saleem. 2020. Social and Cognitive Aspects of Women Entrepreneurs: Evidence from India. The Journal for Decision Makers 45: 223-39. [CrossRef]

Baig, Umair, Batool Muhammad Hussain, Vida Davidaviciene, and Ieva Meidute-Kavaliauskiene. 2021. Exploring Investment Behaviour of Women Entrepreneur: Some Future Directions. International Journal of Financial Studies 9: 20. [CrossRef]

Baker, H. Kent, Satish Kumar, and Harsh Pratap Singh. 2018. Behavioural biases among SME owners. International Journal of Management Practice 11: 259-83. [CrossRef]

Baporikar, Neeta, and Sigried Shikokola. 2020. Enhancing Innovation Adoption to Boost SMEs Performance. International Journal of Innovation in the Digital Economy 11: 1-20. [CrossRef]

Baporikar, Neeta, and Susan Akino. 2020. Financial Literacy Imperative for Success of Women Entrepreneurship. International Journal of Innovation in the Digital Economy 11: 1-21. [CrossRef]

Barber, Brad, and Terrance Odean. 1998. The Common Stock Investment Performance of Individual Investors. SSRN Electronic Journal 2: 773-806. [CrossRef]

Baum and Ingram. 1998. Survival-Enhancing Learning in the Manhattan Hotel Industry, 1898-980. Management Science 44: $996-1016$. [CrossRef]

Bazley, William J., Yosef Bonaparte, and George M. Korniotis. 2020. Financial Self-awareness: Who Knows What They Don't Know? Finance Research Letters 38: 101445. [CrossRef]

Benartzi, Shlomo, and Richard Thaler. 1995. Myopic Loss Aversion and the Equity Premium Puzzle. The Quarterly Journal of Economics 110: 73-92. [CrossRef]

Bianchi, Milo. 2018. Financial Literacy and Portfolio Dynamics: Financial Literacy and Portfolio Dynamics. The Journal of Finance 73: 831-59. [CrossRef]

Bracha, Anat, and Donald J. Brown. 2012. Affective decision making: A theory of optimism bias. Games and Economic Behavior 75: 67-80. [CrossRef]

Brown, Sarah, and Karl Taylor. 2014. Household finances and the 'Big Five' personality traits. Journal of Economic Psychology 45: 197-212. [CrossRef]

Bucciol, Alessandro, and Luca Zarri. 2017. Do personality traits influence investors' portfolios? Journal of Behavioral and Experimental Economics 68: 1-12. [CrossRef]

Bucciol, Alessandro, and Marcella Veronesi. 2014. Teaching children to save: What is the best strategy for lifetime savings? Journal of Economic Psychology 45: 1-17. [CrossRef]

Calcagno, Riccardo, and Chiara Monticone. 2015. Financial literacy and the demand for financial advice. Journal of Banking and Finance 50: 363-80. [CrossRef]

Camerer, Colin, and Dan Lovallo. 1999. Overconfidence and Excess Entry: An Experimental Approach. The American Economic Review 89: 13. [CrossRef]

Chandra, Abhijeet, and Ravinder Kumar. 2012. Factors Influencing Indian Individual Investor Behaviour: Survey Evidence. SSRN Electronic Journal 39: 141-167. [CrossRef]

Chavali, Kavita, and Prasanna Mohan Raj. 2016. Impact of demographic variables and risk tolerance on investment decisions: An empirical analysis. International Journal of Economics and Financial Issues 6: 169-75.

Chin, Wynne. 2010. How to Write Up and Report PLS Analyses. In Handbook of Partial Least Squares. Edited by Vincenzo Esposito Vinzi, Wynne W. Chin, Jörg Henseler and Huiwen Wang. Berlin/Heidelberg: Springer, pp. 655-90. [CrossRef]

Cooke, Fang Lee, and Mengtian Xiao. 2021. Women entrepreneurship in China: Where are we now and where are we heading. Human Resource Development International 24: 104-21. [CrossRef]

Davis, Aeron. 2006. The role of the mass media in investor relations. Journal of Communication Management 10: 7-17. [CrossRef] 
Elam, Amanda B., Candida G. Brush, Patricia G. Greene, Benjamin Baumer, Monica Dean, and René Heavlow. 2019. Women's Entrepreneurship Report 2018/2019. Wellesley: Babson College, Smith College, and the Global Entrepreneurship Research Association (GERA), GEM Consortium.

Eysenck, Hans Jurgen. 1991. Dimensions of personality: 16, 5 or 3? Criteria for a taxonomic paradigm. Personality and Individual Differences 12: 773-90. [CrossRef]

Filbeck, Greg, Patricia Hatfield, and Philip Horvath. 2005. Risk Aversion and Personality Type. Journal of Behavioral Finance 6: 170-80. [CrossRef]

Fisher, Kenneth, and Meir Statman. 2000. Cognitive Biases in Market Forecasts. The Journal of Portfolio Management 27: 72-81. [CrossRef]

Fornell, Claes, and David Larcker. 1981. Evaluating Structural Equation Models with Unobservable Variables and Measurement Error. Journal of Marketing Research 12: 39-50. [CrossRef]

Godoi, Christiane Kleinübing, Rosilene Marcon, and Anielson Barbosa DaSilva. 2005. Loss aversion: A qualitative study in behavioural finance. Managerial Finance 31: 46-56. [CrossRef]

Griffin, Mark, and Gudela Grote. 2020. When Is More Uncertainty Better? A Model of Uncertainty Regulation and Effectiveness. Academy of Management Review 45: 745-65. [CrossRef]

Grohmann, Antonia, Roy Kouwenberg, and Lukas Menkhoff. 2015. Childhood roots of financial literacy. Journal of Economic Psychology 51: 114-33. [CrossRef]

Hair, Joe, Christian Ringle, and Marko Sarstedt. 2011. PLS-SEM: Indeed, a silver bullet. Journal of Marketing Theory and Practice 19: 139-52. [CrossRef]

Hair, Joseph, Jeffrey Risher, Marko Sarstedt, and Christian Ringle. 2019. When to use and how to report the results of PLS-SEM. European Business Review 31: 2-24. [CrossRef]

Hair, Joe F., Jr., Marko Sarstedt, Lucas Hopkins, and Volker G. Kuppelwieser. 2014. Partial least squares structural equation modeling (PLS-SEM): An emerging tool in business research. European Business Review 26: 106-21. [CrossRef]

Heaton, James. 2002. Managerial Optimism and Corporate Finance. Financial Management 31: 33. [CrossRef]

Henseler, Jörg, Christian M. Ringle, and Rudolf R. Sinkovics. 2009. The use of partial least squares path modeling in international marketing. In Advances in International Marketing. Edited by R. R. Sinkovics and P. N. Ghauri. Bingley: Emerald Group Publishing Limited, vol. 20, pp. 277-319. [CrossRef]

Hibbert, Jeffery, Ivan Beutler, and Todd Martin. 2004. Financial Prudence and Next Generation Financial Strain. Journal of Financial Counseling and Planning 15: 9.

Hsu, Dan, Johan Wiklund, and Richard Cotton. 2017. Success, Failure, and Entrepreneurial Reentry: An Experimental Assessment of the Veracity of Self-Efficacy and Prospect Theory. Entrepreneurship Theory and Practice 41: 19-47. [CrossRef]

Hsu, Yuan-Lin, Hung-Ling Chen, Po-Kai Huang, and Wan-Yu Lin. 2020. Does financial literacy mitigate gender differences in investment behavioral bias? Finance Research Letters 2020: 101789. [CrossRef]

Imtiaz, Rozina, Syeda Qurat ul Ain Kazmi, Maheen Amjad, and Atif Aziz. 2019. The impact of social network marketing on consumer purchase intention in Pakistan: A study on female apparel. Management Science Letters 9: 1093-104. [CrossRef]

Jöreskog, Karl G. 1971. Simultaneous factor analysis in several populations. Psychometrika 36: 409-26. [CrossRef]

Kahneman, Daniel, and Amos Tversky. 1988. Prospect theory: An analysis of decision under risk. In Decision, Probability and Utility, 1st ed. Edited by P. Gärdenfors and N.-E. Sahlin. Cambridge: Cambridge University Press, pp. 183-214. [CrossRef]

Kahneman, Daniel, and Dan Lovallo. 1993. Timid Choices and Bold Forecasts: A Cognitive Perspective on Risk Taking. Management Science 39: 17-31. [CrossRef]

Kannadhasan, M., S. Aramvalarthan, S. K. Mitra, and Vinay Goyal. 2016. Relationship between Biopsychosocial Factors and Financial Risk Tolerance: An Empirical Study. The Journal for Decision Makers 41: 117-31. [CrossRef]

Kappal, Jyoti, and Shailesh Rastogi. 2020. Investment behaviour of women entrepreneurs. Qualitative Research in Financial Markets 12: 485-504. [CrossRef]

Khresna Brahmana, Rayenda, Chee-Wooi Hooy, and Zamri Ahmad. 2012. Psychological factors on irrational financial decision making: Case of day-of-the week anomaly. Humanomics 28: 236-57. [CrossRef]

Kumar, Satish, and Nisha Goyal. 2015. Behavioural biases in investment decision making-A systematic literature review. Qualitative Research in Financial Markets 7: 88-108. [CrossRef]

Kumar, Satish, Nisha Goyal, and Rituparna Basu. 2018. Profiling emerging market investors: A segmentation approach. International Journal of Bank Marketing 36: 441-55. [CrossRef]

Lakshmi, B. 2015. Factors affecting the investment behaviour of women. International Journal in Management E Social Science 3: 185-97.

Lassoued, Awad, and R. Guirat. 2020. The impact of managerial empowerment on problem solving and decision making skills: The case of Abu Dhabi University. Management Science Letters 10: 769-80. [CrossRef]

Lee, Charles, Andrei Shleifer, and Richard Thaler. 1991. Investor Sentiment and the Closed-End Fund Puzzle. The Journal of Finance 46: 75-109. [CrossRef]

Liao, Li, Jing Jian Xiao, Weiqiang Zhang, and Congyi Zhou. 2017. Financial literacy and risky asset holdings: Evidence from China. Accounting and Finance 57: 1383-415. [CrossRef]

Litt, Mark, Howard Tennen, Glenn Affleck, and Susan Klock. 1992. Coping and Cognitive factors in adaptation toin vitro fertilization failure. Journal of Behavioural Medicine 15: 171-87. [CrossRef] 
Marín, Longinos, Catalina Nicolás, and Alicia Rubio. 2019. How Gender, Age and Education Influence the Entrepreneur's Social Orientation: The Moderating Effect of Economic Development. Sustainability 11: 4514. [CrossRef]

Mayfield, Cliff, Grady Perdue, and Kevin Wooten. 2008. Investment management and personality type. Financial Services Review 17: 219-36.

McColl-Kennedy, Janet, and Ronald Anderson. 2005. Subordinate manager gender combination and perceived leadership style influence on emotions, self-esteem and organizational commitment. Journal of Business Research 58: 115-25. [CrossRef]

McKay, Ruth. 2001. Women entrepreneurs: Moving beyond family and flexibility. International Journal of Entrepreneurial Behaviour and Research 7: 148-65. [CrossRef]

Mishra, K. C., and Mary J. Metilda. 2015. A study on the impact of investment experience, gender, and level of education on overconfidence and self-attribution bias. IIMB Management Review 27: 228-39. [CrossRef]

Muhammad, Said, Ximei Kong, Shahab Saqib, and Nicholas Beutell. 2021. Entrepreneurial Income and Wellbeing: Women's Informal Entrepreneurship in a Developing Context. Sustainability 13: 10262. [CrossRef]

Nath, Leda, Lori Holder-Webb, and Jeffrey Cohen. 2013. Will Women Lead the Way? Differences in Demand for Corporate Social Responsibility Information for Investment Decisions. Journal of Business Ethics 118: 85-102. [CrossRef]

Nigam, Rupali Misra, Sumita Srivastava, and Devinder Kumar Banwet. 2018. Behavioral mediators of financial decision making-A state-of-art literature review. Review of Behavioral Finance 10: 2-41. [CrossRef]

Pandian, Alagu, and G. Thangadurai. 2013. A Study of Investors Preference towards Various Investments Avenues in Dehradun District. International Journal of Management and Social Sciences Research (IJMSSR) 2: 10.

Parsaeemehr, Mahsa, Farzin Rezeai, and Darshana Sedera. 2013. Personality type of investors and perception of financial information to make decisions. Asian Economic and Financial Review 11: 283-293.

Pompian, Michael M. 2006. Behavioral Finance and Wealth Management: How to Build Optimal Portfolios that Account for Investor Biases. Hoboken: John Wiley \& Sons.

Rashid, Sumayya, and Vanessa Ratten. 2020. Commodifying skills for survival among artisan entrepreneurs in Pakistan. International Entrepreneurship and Management Journal 17: 1091-1110. [CrossRef]

Rigdon, Edward E. 2012. Rethinking partial least squares path modeling: In praise of simple methods. Long Range Planning 45: 341-58. [CrossRef]

Ritter, Jay R. 2003. Behavioral finance. Pacific-Basin Finance Journal 11: 429-37. [CrossRef]

Sahi, Shalini Kalra, Ashok Pratap Arora, and Nand Dhameja. 2013. An Exploratory Inquiry into the Psychological Biases in Financial Investment Behavior. Journal of Behavioral Finance 14: 94-103. [CrossRef]

Sajjad, Muhammad, Nishat Kaleem, Muhammad Irfan Chani, and Munir Ahmed. 2020. Worldwide role of women entrepreneurs in economic development. Asia Pacific Journal of Innovation and Entrepreneurship 14: 151-60. [CrossRef]

Salim, Ansa Savad, Mohammed Ahmed Hamood Al Jahdhami, and S. N. S. A. Al Handhali. 2016. A study on Customer preferences towards selected local Omani (FMCG) products. International Journal of Science and Research (IJSR) 6: 1273-77.

Salim, Ansa, and Sania Khan. 2020. The effects of factors on making investment decisions among Omani working women. Accounting. Accounting 6: 657-64. [CrossRef]

Sarkar, Arup Kumar, and Tarak Nath Sahu. 2018. Investment Behaviour: Towards an Individual-Centred Financial Policy in Developing Economies. Emerald Publishing Limited. [CrossRef]

Shakeel, Muhammad, Yaokuang Li, and Ali Gohar. 2020. Identifying the Entrepreneurial Success Factors and the Performance of Women-Owned Businesses in Pakistan: The Moderating Role of National Culture. SAGE Open 10. [CrossRef]

Shiller, Robert J. 2000. Measuring Bubble Expectations and Investor Confidence. Journal of Psychology and Financial Markets 1: 49-60. [CrossRef]

Shiller, Robert, and John Pound. 1989. Survey evidence on diffusion of interest and information among investors. Journal of Economic Behavior and Organization 12: 47-66. [CrossRef]

Shmueli, Galit, and Otto Koppius. 2011. Predictive Analytics in Information Systems Research. MIS Quarterly 35: 553-72. [CrossRef]

Son, JeongWook, and Eddy Rojas. 2011. Impact of Optimism Bias Regarding Organizational Dynamics on Project Planning and Control. Journal of Construction Engineering and Management 137: 147-57. [CrossRef]

Soomro, Bahadur Ali, Hassan Almahdi, and Naimatullah Shah. 2020. Perceptions of young entrepreneurial aspirants towards sustainable entrepreneurship in Pakistan. Kybernetes 50: 2134-54. [CrossRef]

Stefan, Daniel, Valentina Vasile, Anca Oltean, Calin-Adrian Comes, Anamari-Beatrice Stefan, Liviu Ciucan-Rusu, Elena Bunduchi, Maria-Alexandra Popa, and Mihai Timus. 2021. Women Entrepreneurship and Sustainable Business Development: Key Findings from a SWOT-AHP Analysis. Sustainability 13: 5298. [CrossRef]

Stolper, Oscar. 2018. It takes two to Tango: Households' response to financial advice and the role of financial literacy. Journal of Banking and Finance 92: 295-310. [CrossRef]

Tang, Ning, and Andrew Baker. 2016. Self-esteem, financial knowledge and financial behavior. Journal of Economic Psychology 54: 164-76. [CrossRef]

Thaler, Richard H. 2008. Mental accounting and consumer choice. Marketing Science 27: 15-25. [CrossRef]

Trevelyan, Rose. 2008. Optimism, overconfidence and entrepreneurial activity. Management Decision 46: 986-1001. [CrossRef]

Van Rooij, Maarten, Annamaria Lusardi, and Rob Alessie. 2011. Financial literacy and stock market participation. Journal of Financial Economics 101: 449-72. [CrossRef] 
Van Truong, Doan, Nguyen Giao, and Le Thi Thuy Ly. 2020. Factors affecting the role of women in the economic development of rural household families in Vietnam: A case study in Trieu Son district Thanh Hoa province. Accounting 6: 267-72. [CrossRef]

Webley, Paul, and Ellen Nyhus. 2006. Parents' influence on children's future orientation and saving. Journal of Economic Psychology 27: 140-64. [CrossRef]

Wetzels, Martin, Gaby Odekerken-Schröder, and Claudia Van Oppen. 2009. Using PLS path modelling for assessing hierarchical construct models: Guidelines and empirical illustration. MIS Quarterly 33: 177-95. [CrossRef]

Wing Yan Man, Thomas. 2006. Exploring the behavioural patterns of entrepreneurial learning: A competency approach. Education $\mathcal{E}$ Training 48: 309-21. [CrossRef]

Yaqoob, Samina. 2020. The Emerging trend Women entrepreneurship in Pakistan: Women entrepreneurship. Journal of Arts and Social Sciences 7: 217-30. [CrossRef]

Zahera, Syed Aliya, and Rohit Bansal. 2018. Do investors exhibit behavioural biases in investment decision making? A systematic review. Qualitative Research in Financial Markets 10: 210-51. [CrossRef]

Zeb, Arooj, and Anjum Ihsan. 2020. Innovation and the entrepreneurial performance in women-owned small and medium-sized enterprises in Pakistan. Women's Studies International Forum 79: 102342. [CrossRef] 